\title{
The mutagenicity of organic extracts in source water and peripheral water with different disinfection ways
}

\author{
Yi Zhong ${ }^{1}$, Xiao-Tong Li ${ }^{1}$, Qi-Yi Huang ${ }^{2}$, Ren-De Huang ${ }^{1}$, Zi-Yan Zhou ${ }^{1}$, Hua Bi ${ }^{1}$, Peng-Ya Feng ${ }^{3}$, De-Dong Wang ${ }^{1}{ }^{*}$ \\ ${ }^{1}$ Guangzhou Center for Disease Control and Prevention, Guangzhou 510440, P.R. China \\ ${ }^{2}$ Guangdong Industry Polytechnic, Guangzhou 510260, P.R. China \\ ${ }^{3}$ Guangdong Provincial Key Laboratory of Tropical Disease Research, School of Public Health, Southern Medical University, Guangzhou \\ 510515, P.R. China
}

\begin{abstract}
This study aimed to determine mutagen contamination, to compare the differences between inlet and outlet distribution, and the possible impacts on public health. Water samples were collected from four different waterworks in Guangzhou, China. The Ames test was conducted to investigate the potential mutagenicity caused by organic extracts from drinking water sources and peripheral water. Organic content was extracted with XAD-2 resin column and organic solvents, and toxicity was tested in three doses of extract equivalent, $0.2,0.4$ and $0.8 \mathrm{~L}$ source water. The results of the Ames test showed that all the organic extracts from water samples could induce different levels of mutagenic potentials in the absence of S9 mix, which indicated mutagenicity and strain. Comparing with TA98, TA100 was more sensitive in genotoxicity. Mutagenic enhancement factors were found in both drinking water sources and peripheral water. Water treatment technologies with different disinfection ways could increase the mutagenicity of water, but the biological significance of mutagenicity of the organic extracts remained to be further confirmed. The results suggested that it was necessary to concern the relationship between source water, water treatment unit and the mutagenicity factors of water.
\end{abstract}

Keywords: Mutagenicity, organic extracts, source water, peripheral water, disinfection

* Correspondence to: De-Dong Wang, Guangzhou Center for Disease Control and Prevention, Guangzhou 510440, P.R. China;

E-mail: wangdedong_66@163.com

Received: Noverber 9, 2018; Accepted: March 19, 2019; Published Online: May 1, 2019

Citation: Yi Zhong, Xiao-Tong Li, Qi-Yi Huang, Ren-De Huang, Zi-Yan Zhou, Hua Bi, Guo-Xia Zhang, De-Dong Wang, 2019. The mutagenicity of organic extracts in source water and peripheral water with different disinfection ways. Applied Environmental Biotechnology, 4(2): 39-43. http://doi.org/10.26789/AEB.2019.01.008

Copyright: Current Status and Development of Remediation for Heavy Metals in China.@ 2019 De-Dong Wang et al.. This is an Open Access article distributed under the terms of the Creative Commons Attribution-Noncommercial 4.0 International License, permitting all non-commercial use, distribution, and reproduction in any medium, provided the original work is properly cited and acknowledged.

\section{Introduction}

Drinking water can be contaminated at the original water source, during treatment, in distributional pipes from treatment facilities to homes and businesses, or in containers post-treatment (Gilbert and Rose, 2012). Conventional treatment adopted by the majority of waterworks in the China, usually includes rapid mixing, coagulation, flocculation, sedimentation, filtration and disinfection. The disinfection of drinking water could produce by-products which may cause adverse health effects to the public (Hou et al., 2012; Zhao et al., 2012).

Ames test can well stimulate the process of the water quality assessment for organic contaminants. Identifying the pollution, especially if caused by organic chemicals, is not economically and practically cost-effective due to the complex molecular structure of organic chemicals in the aquatic environment. Among these pollutants, the detection of mutagenes in aquatic environment is of great importance because of their abilities to induce cancer and potential damage to the germ line, which may lead to fertility problems and genetic damages among the future generations (Kutlu et al., 2004). Therefore, short-term bioassays coupled with chemical analysis are a valuable technique to assessing toxic components in environmental samples (Schuetzle and Lewtas, 1986). Of these bioassays, Salmonella typhimurium/microsome test is one of the most important methods with well-acknowledged accuracy (Maron and Ames, 1983). Salmonella mutagenicity assay (Ames test) was specially designed to detect chemically induced mutagenesis. Numerous studies had reported the mutagenicity of complex mixtures in river water and sediments, lakes, industrial effluents and drinking waters using Salmonella mutagenicity test systems (Filipic and Toman, 1996; Hollert et al., 2000; Kataoka et al., 2000; Mamber et al., 1993; Cerna et al., 1998).

It is expected that the survey data would be helpful for disinfection by-products (DBPs) health risk assessment, regulation and water treatment process optimization. Chlorination is used to kill pathogenic microorganisms in tap water and can effectively prevent and control waterborne infectious disease epidemic, with the advantages of low cost 
and being easy to use. In the recent decades, research have showed that the chlorination use in tap water could produce three halogenated methane carcinogenic, tumour and other organic halides. The safety problem has already gained great pubic attention. At present, a considerable large number of waterworks and operated by medium and small factories and township water choose chlorine dioxide disinfection, and a small number of large chemical plant owned water, pure water, water quality sub district etc. In order to understand the effects of different disinfection methods on mutagenicity of machine extracts, using Ames test, the liquid chlorine, Chlorine dioxide, ozone disinfection before and after the samples were induced by organic extracts mutation detection, and provide scientific basis for the choice of drinking water disinfection method.

This study aimed to investigate the possible contamination by mutagenic substances in the water from four waterworks which may play a role in population health. For this purpose, two strains of Salmonella typhimurium with frameshift mutation (TA 98) and base-pair substitution mutation (TA 100) were used in plate incorporation assay in the absence of metabolic activation.

\section{Materials and Methods}

\subsection{Chemicals and Pretreatment}

Agar and nutrient broth medium were purchased from Sigma (St. Louis, USA). Amberlite XAD-2 resins were purchased from Beijing Beishi Zongheng science and technology development co., LTD. All other chemical reagents were of the highest commercial quality available.

A further cleaning was conducted for XAD-2 resins with methanol and dichloromethane in a Soxhlet extractor system. Then, the pre-cleaned XAD-2 resins were soaked in methanol. The resins column was eluted with $500 \mathrm{~mL}$ deionized water before use. All the glass containers were pre-cleaned by potassium dichromate-sulfuric acid solutions and kilned at $450{ }^{\circ} \mathrm{C}$ for $5 \mathrm{~h}$.

\subsection{Sample Collection}

Water samples were collected in the source water from 4 different sampling sites including Suiyun, Xichun, Xintang and Nanzhou in dry periods from October 2012 to November 2012. Almost $70 \%$ of drinking water of Guangzhou city is from mentioned regions. At each sampling site, $20 \mathrm{~L}$ of water was collected with pre-cleaned glass bottles and then combined to $200 \mathrm{~L}$ for later analysis.

\subsection{Sample Concentration}

After collectiong, water samples were stored in at $4{ }^{\circ} \mathrm{C}$ for 24 $\mathrm{h}$, and then each water sample was passed through XAD-2 to extract organic pollutants. The XAD-2 was pre-cleaned by consecutive Soxhlet extractions with acetone, $n$-hexane, and methanol (10 h each) and kept in methanol until field application in the batch-wise extraction. The velocity of flow was 30-40 mL/min. Organic matter was eluted with $300 \mathrm{~mL}$ dichloromethane /hexanex (85/15) and $200 \mathrm{~mL}$ acetone (rate of $3-5 \mathrm{~mL} / \mathrm{min}$ ). The organic solvents were evaporated to a small volume at $40{ }^{\circ} \mathrm{C}$ under reduced pressure by a rotary evaporator, and then dried by blowing with a nitrogen stream. The dry residue was re-dissolved in $3.0 \mathrm{~mL}$ DMSO $(20 \mathrm{~L}$ water equivalent $/ \mathrm{mL}$ ). Further dilutions were performed as necessary. Samples were stored in a freezer at $-20{ }^{\circ} \mathrm{C}$ until use.

\subsection{Ames Test}

The tester strains TA98 and TA100 were obtained from Wuhan Institute of Environmental Medicine, Tongji Medical College, Huazhong University of Science and Technology. The procedure of Ames test without metabolic activation was carried out as described (Blaise et al., 1994) with modifications. The overnight grown cell suspensions (approximately $10^{8}$ cell $/ \mathrm{mL}$ ) of Salmonella typhimurium histidine autotrophs TA98 and TA100 were diluted tenfold with sterile distilled water. Four dilutions $(0.2,0.4$, and $0.8 \mathrm{~L}$ are equal to source water respectively) of water samples were used for toxic analysis. The diluted test sample $(0.1 \mathrm{~mL})$ and bacterial culture $(0.1 \mathrm{~mL})$ were thoroughly mixed with $2.5 \mathrm{~mL}$ of molten top agar $(0.6 \%$ agar and $0.5 \% \mathrm{NaCl})$ and poured over the surface of Vogel-Bonner minimal agar plate $(1.5 \%$ agar, $0.4 \%$ glucose, $2 \% \mathrm{~K}_{2} \mathrm{HPO}_{4}, 0.7 \% \mathrm{NaNH}_{4} \mathrm{HPO}_{4} \cdot 4 \mathrm{H}_{2} \mathrm{O}$, and $0.04 \%$ $\mathrm{MgSO}_{4} \cdot 7 \mathrm{H}_{2} \mathrm{O}$ ). The top agar was allowed to solidify, and the plates were incubated in the dark at $37^{\circ} \mathrm{C}$ for $48 \mathrm{~h}$. Subsequently, the number of revertants and surviving colonies formed per plate, against a background lawn of growth, were counted. 4-Nitroquinoline 1-oxide was used as positive controls and sterile distilled water as a negative control. The mutagenic effect was evaluated by the number of revertant colonies per plates. The plates were prepared in triplicate for every test sample. The sample was considered as positive response only if the mutation rate (MR) was equal to or above 2.00 ( $\mathrm{MR}=$ mutant colonies on test plate/spontaneous mutant colonies on negative control plate) and dose-response relationship was observed.

\subsection{Statistical Analysis}

Pearson correlation, one-way analysis of variance (ANOVA) and ordinary least-squares linear regression analysis were performed by IBM SPSS 19.0 software. The result presented was the mean of triplicate observation ( \pm standard deviation). The effects of different doses were compared by means of statistical analysis (Bernstein et al., 1982). ANOVA was used to compare the mutagenic potency or induction ratio in two seasons, genotoxicity induced by all the control and water samples. This study set the statistic significant level at 0.05 . 


\section{Results}

\subsection{The Mutagenic Potential of Organic Extracts at Different Concentration in Source Water and Peripheral Water by Ames Test}

The mutagenic potentials of three doses (equivalent to 0.2 , 0.4 and 0.8 liter water) of organic extracts from water samples in four different zones of Guangzhou were analyzed in three equal intervals on two different strains TA 98 and TA 100. The Mutagenic Index (MI) was calculated for each assay and compered with negative control. The results of the mutagenicity of solvent extracts of source water samples from different waterworks were shown in Table 1. Results showed that the number of revertants was increased but none of them were two-fold of the number of colonies in solvent control. Sample XT has the most revertants at both the dose $0.4 \mathrm{~L}$ and $0.8 \mathrm{~L}$ group on strain TA 100. Sample XC has less revertants than other samples in high dose group on strain TA98.

Table 1. Mutagenic potencies of source water samples analyzed by the Salmonella assay

\begin{tabular}{|c|c|c|c|c|c|c|c|}
\hline \multirow{2}{*}{ Dose } & \multirow{2}{*}{ Waterworks } & \multicolumn{3}{|c|}{ TA100 } & \multicolumn{3}{|c|}{ TA98 } \\
\hline & & Revertants & F value & $P$ value & Revertants & F value & $P$ value \\
\hline \multirow{4}{*}{0.2} & SY & $120.67 \pm 3.21$ & \multirow{4}{*}{2.01} & \multirow{4}{*}{0.1912} & $29.67 \pm 0.58$ & \multirow{4}{*}{0.65} & \multirow{4}{*}{0.6034} \\
\hline & $\mathrm{XC}$ & $123.33 \pm 1.15$ & & & $30.33 \pm 3.21$ & & \\
\hline & XT & $124.00 \pm 3.00$ & & & $28.67 \pm 2.08$ & & \\
\hline & $\mathrm{NZ}$ & $125.33 \pm 1.53$ & & & $27.33 \pm 4.04$ & & \\
\hline \multirow{4}{*}{0.4} & SY & $133.00 \pm 1.41^{\mathrm{b}}$ & \multirow{4}{*}{10.11} & \multirow{4}{*}{0.0061} & $34.67 \pm 2.52$ & \multirow{4}{*}{1.76} & \multirow{4}{*}{0.2331} \\
\hline & $\mathrm{XC}$ & $132.00 \pm 2.65^{\mathrm{b}}$ & & & $32.33 \pm 3.21$ & & \\
\hline & XT & $151.67 \pm 8.39^{\mathrm{a}}$ & & & $36.00 \pm 1.73$ & & \\
\hline & $\mathrm{NZ}$ & $138.67 \pm 1.53^{\mathrm{b}}$ & & & $38.00 \pm 4.36$ & & \\
\hline \multirow{4}{*}{0.8} & SY & $163.67 \pm 5.51^{\mathrm{b}}$ & \multirow{4}{*}{24.09} & \multirow{4}{*}{0.0005} & $54.00 \pm 4.24^{\mathrm{a}}$ & \multirow{4}{*}{7.81} & \multirow{4}{*}{0.0123} \\
\hline & $\mathrm{XC}$ & $152.33 \pm 5.03^{b}$ & & & $38.33 \pm 2.52^{b}$ & & \\
\hline & XT & $188.67 \pm 7.57^{\mathrm{a}}$ & & & $59.00 \pm 8.89^{\mathrm{a}}$ & & \\
\hline & $\mathrm{NZ}$ & $155.50 \pm 0.71^{\mathrm{b}}$ & & & $52.00 \pm 3.00^{\mathrm{a}}$ & & \\
\hline
\end{tabular}

Notes: ${ }^{a, b}$ The comparison show statistically significant difference among different groups.

\subsection{The Mutagenic Potential of Organic Ex- tracts in Source Water and Peripheral Water form Different Positions by Ames Test}

In some periods, the numbers of revertants were decreased comparing to solvent control which indicated the toxic effect slowed down the growth of colonies. The tests using TA98 strains of $S$. typhimurium showed that the source water samples had toxic effect which was clearly understood. On the other hand, the tests using TA100 strain showed no mutagenic but strong toxic effect on bacterial colonies at XT while the number of the revertants increased up to 1.5 in MI value at the middle and high dose group (Table 2).

\section{Discussion}

The quality of drinking water is highly associated with several health-related concerns such as microbial and chemical pollutants (Abda et al., 2015; Karyab et al., 2013). Many investigations have emphasized on the risk assessment of drinking water to strength current authorities and reduce the possible health risks resulting from tracible hazardous pollutants in drinking waters (Bain et al., 2014). The aim of the present study was to investigate the potential for contamination by mutagenic substances in drinking waterworks in Guangzhou City, China using Salmonella mutagenicity systems (Ames test).

Worldwide, some purification methods of water like $\mathrm{H}_{2} \mathrm{O}_{2}$ and chlorination may cause formation of carcinogenic disinfection by-products because of the intensified pollution of water supplies to organic matters (Villanueva et al., 2014). In fact, these widely used methods for disinfection in drinking water are responsible for more than half of positive Ames mutagenicity in apparently purified waters assessed by Salmonella mutagenicity systems (Ames test) which is a simple biological assay to assess the mutagenic potential of chemicals which has been widely used in the screening of chemicals (Kusamran et al., 2003).

It should be pointed out that the Ames test was to identify the most significant sites for initial assessment of the basin presence of mutagenic compounds (Vargas et al., 1993). Ames test was performed on water and sediment samples from Porsuk River without metabolic activation using TA98 and TA100 strains and found mutagenic and toxic effects with both strains at 5 different concentrations and in different sampling sites (Kutlu et al., 2004). One study in India reported the extracts of the Penobscot River water and sediments and Penobscot drinking water had little to no mutagenic activity using the Salmonella mutagenicity assay detects (Warren et al., 2015). 0.5, 1, 2, 4-liter water of organic extracts from raw, treated and drinking waters sampled from seven different treatment plants in five cities in Korea were challenged to the Ames test using S. typhimurium strains TA98 and TA100. The mutagenicity was usually observed from chlorine-treated $(28.6 \%)$ and drinking $(42.9 \%)$ waters rather than raw $(3.4 \%)$ waters. The strain TA98 (33.3\%) was more sensitive to detect the mutagenicity of water samples than the strain TA100 (16.7\%). However, the absence of S9 mix showed higher mutagenic activity of waters compared to the presence of S9 mix, corresponding to the detection of $42.9 \%$ and $7.1 \%$, respectively. These results indicated that the bacterial mutagenicity of treated and drinking waters may be derived from chlorination in water treatment plants, but the mutagenicity in humans may be limited due to enzymatic metabolism. In China, water quality monitoring is also necessary and feasible. Some studies have indicated mutagenic potential of drinking water. For instance, all water extracts from the Yangtze River and Hanshui River caused dose-dependent DNA mutation at certain concentrations, and mutagenicity varied during different seasons (Liu et al., 2011; Wu et al., 2004; Yuan et al., 2005). Lv and colleague sevaluated the mutagenicity of the water samples using the Ames test with Salmonella 
Table 2. Mutagenic potencies of source water samples analyzed by the Salmonella assay

\begin{tabular}{|c|c|c|c|c|c|c|c|c|}
\hline \multirow{2}{*}{$\begin{array}{l}\text { Water } \\
\text { works }\end{array}$} & \multirow{2}{*}{ Sorts } & \multirow{2}{*}{ Dose } & \multicolumn{3}{|c|}{ TA100 } & \multicolumn{3}{|c|}{ ТА98 } \\
\hline & & & Revertants & F value & $P$ value & Revertants & F value & $P$ value \\
\hline \multirow{6}{*}{ SY } & \multirow{3}{*}{$\begin{array}{l}\text { Source } \\
\text { water }\end{array}$} & 0.2 & $120.67 \pm 3.21^{\mathrm{c}}$ & 86.99 & $0.0001^{\mathrm{f}}$ & $29.67 \pm 0.58^{\text {bde }}$ & 60.04 & 0.0003 \\
\hline & & 0.4 & $133.00 \pm 1.41^{\text {bde }}$ & 94.01 & $<0.0001^{\mathrm{g}}$ & $34.67 \pm 2.52^{\text {bde }}$ & 57.67 & $<0.0001$ \\
\hline & & 0.8 & $163.37 \pm 5.51^{\mathrm{ade}}$ & 99.02 & $<0.0001^{\mathrm{h}}$ & $54.00 \pm 4.24^{\text {ade }}$ & 90.47 & $<0.0001$ \\
\hline & \multirow{3}{*}{$\begin{array}{l}\text { Periphe- } \\
\text { ral water }\end{array}$} & 0.2 & $144.33 \pm 4.04^{\text {cde }}$ & 25.33 & $0.0012^{\mathrm{f}}$ & $28.67 \pm 2.52^{\mathrm{ce}}$ & 142.12 & $<0.0001$ \\
\hline & & 0.4 & $155.33 \pm 2.08^{\text {bde }}$ & 91.97 & $<0.0001^{\mathrm{g}}$ & $46.33 \pm 0.58^{\text {bde }}$ & 142.6 & $<0.0001$ \\
\hline & & 0.8 & $166.33 \pm 4.73^{\text {ade }}$ & 100.06 & $<0.0001^{\mathrm{h}}$ & $63.00 \pm 3.46^{\text {ade }}$ & 210.08 & $<0.0001$ \\
\hline \multirow{6}{*}{$\mathrm{XC}$} & \multirow{3}{*}{$\begin{array}{l}\text { Source } \\
\text { water }\end{array}$} & 0.2 & $123.33 \pm 1.15^{\mathrm{c}}$ & 59.24 & 0.0001 & $30.33 \pm 3.21^{\text {bde }}$ & 5.78 & 0.0399 \\
\hline & & 0.4 & $132.00 \pm 2.65^{\text {bde }}$ & 63.81 & $<0.0001$ & $32.33 \pm 3.21^{\text {bde }}$ & 13.33 & 0.0018 \\
\hline & & 0.8 & $152.33 \pm 5.03^{\text {ade }}$ & 68.81 & $<0.0001$ & $38.33 \pm 2.52^{\text {ade }}$ & 18.35 & 0.0006 \\
\hline & \multirow{3}{*}{$\begin{array}{l}\text { Periphe- } \\
\text { ral water }\end{array}$} & 0.2 & $125.00 \pm 2.65^{\mathrm{c}}$ & 129.34 & $<0.0001$ & $23.67 \pm 1.15^{\mathrm{c}}$ & 33.05 & 0.0006 \\
\hline & & 0.4 & $133.00 \pm 4.58^{\text {bde }}$ & 136.83 & $<0.0001$ & $29.67 \pm 2.08^{\mathrm{be}}$ & 28.95 & 0.0001 \\
\hline & & 0.8 & $172.00 \pm 4.00^{\mathrm{ade}}$ & 143.63 & $<0.0001$ & $43.00 \pm 4.58^{\mathrm{ade}}$ & 38.93 & $<0.0001$ \\
\hline \multirow{6}{*}{ XT } & \multirow{3}{*}{$\begin{array}{l}\text { Source } \\
\text { water }\end{array}$} & 0.2 & $124.00 \pm 3.00^{\mathrm{c}}$ & 69.32 & $<0.0001$ & $28.67 \pm 2.08^{b}$ & 26.11 & 0.0011 \\
\hline & & 0.4 & $151.67 \pm 8.39^{\text {bde }}$ & 82.84 & $<0.0001$ & $36.00 \pm 1.73^{\text {bde }}$ & 31.47 & $<0.0001$ \\
\hline & & 0.8 & $188.67 \pm 7.57^{\text {ade }}$ & 85.34 & $<0.0001$ & $59.00 \pm 8.89^{\text {ade }}$ & 35.04 & $<0.0001$ \\
\hline & \multirow{3}{*}{$\begin{array}{l}\text { Periphe- } \\
\text { ral water }\end{array}$} & 0.2 & $139.00 \pm 5.29^{\text {cde }}$ & 364.22 & $<0.0001$ & $37.67 \pm 1.15^{\text {cde }}$ & 41.67 & 0.0003 \\
\hline & & 0.4 & $162.33 \pm 1.15^{\text {bde }}$ & 455.17 & $<0.0001$ & $68.67 \pm 8.33^{\text {bde }}$ & 74.19 & $<0.0001$ \\
\hline & & 0.8 & $238.33 \pm 6.11^{\text {ade }}$ & 468.67 & $<0.0001$ & $81.00 \pm 6.08^{\mathrm{ade}}$ & 80.88 & $<0.0001$ \\
\hline \multirow{6}{*}{$\mathrm{NZ}$} & \multirow{3}{*}{$\begin{array}{l}\text { Source } \\
\text { water }\end{array}$} & 0.2 & $125.33 \pm 1.53^{\mathrm{ce}}$ & 278.4 & $<0.0001$ & $27.33 \pm 4.04^{\mathrm{c}}$ & 31.07 & 0.0007 \\
\hline & & 0.4 & $138.67 \pm 1.53^{\text {bde }}$ & 257.42 & $<0.0001$ & $38.00 \pm 4.36^{\text {bde }}$ & 37.56 & $<0.0001$ \\
\hline & & 0.8 & $155.50 \pm 0.71^{\text {ade }}$ & 315.85 & $<0.0001$ & $52.00 \pm 3.00^{\text {ade }}$ & 45.57 & $<0.0001$ \\
\hline & \multirow{3}{*}{$\begin{array}{l}\text { Periphe- } \\
\text { ral water }\end{array}$} & 0.2 & $129.33 \pm 4.04^{\mathrm{c}}$ & 107.11 & $<0.0001$ & $32.67 \pm 2.08^{\mathrm{cde}}$ & 21.64 & 0.0018 \\
\hline & & 0.4 & $168.00 \pm 2.65^{\text {bde }}$ & 138.84 & $<0.0001$ & $44.33 \pm 3.79^{\text {bde }}$ & 37.64 & $<0.0001$ \\
\hline & & 0.8 & $213.00 \pm 11.14^{\text {ade }}$ & 142.36 & $<0.0001$ & $55.67 \pm 6.03^{\text {ade }}$ & 44.31 & $<0.0001$ \\
\hline \multirow[t]{5}{*}{ Notes: } & \multicolumn{8}{|c|}{ a,b,c The pairwise comparison show statistically significant difference between three groups; } \\
\hline & \multirow{3}{*}{\multicolumn{8}{|c|}{$\begin{array}{l}\text { d Statistically significant difference between every dose group and negative control group } \\
{ }^{\text {e }} \text { Statistically significant difference between every dose group and reagent group; } \\
{ }^{\mathrm{f}} \text { The comparison among three dose groups; }\end{array}$}} \\
\hline & & & & & & & & \\
\hline & & & & & & & & \\
\hline & \multicolumn{8}{|c|}{$\begin{array}{l}{ }^{\mathrm{g}} \text { The mean comparisons between three dose groups and the negative control group; } \\
{ }^{\mathrm{h}} \text { The mean comparisons between three dose groups and the reagent group. }\end{array}$} \\
\hline
\end{tabular}

typhimurium strains TA98 and TA100 (Lv et al., 2015). It was found that the organic compounds in the water were largely frame-shift mutagens, and the finished water samples exhibited stronger mutagenicity than the relative raw and distribution water samples. In this study, all stations exhibited toxic properties in at least one dose and with at least one of two strains in mutagenicity study. In the related studies, toxic effects of the source water samples on bacteria were observed on the basis of significantly reduced number of the revertants compared to the solvent controls. Furthermore, to evaluate the use of disinfectant as a pretreatment in four waterworks, the MI value and revertants were compared at each strain of Salmonella test. For strains TA 98 and TA 100, more revertants were found in peripheral water, which means disinfectant may increase the toxic effect. Toxicity ability of organic extracts from source water was $\mathrm{XT}>\mathrm{SY}=\mathrm{XC}=\mathrm{NZ}$ and $\mathrm{XT}>\mathrm{SY}>\mathrm{NZ}>\mathrm{XC}$ for strains TA 100 and TA98, respectively. Nearly all stations had an increase after treatment.

In conclusion, the data of this study proved that all the organic extracts from the water samples could induce different levels of mutagenic potentials in the absence of S9 mix, which demonstrated the existence of mutagenicity and strain TA100 was more sensitive. It further indicated that the Ames test (TA 98 and TA 100) is an appropriate method for primary screening of mutagenic effects of some possible chemical compounds in drinking water.

\section{Acknowledgments}

This work was supported by the Guangzhou medicine and health care technology projects under Grant (number 20141A011060).

\section{References}

Abda, A., Benouareth, D.E., Tabet, M., Liman, R., Konuk, M., Khallef, M. and Taher A., 2015. Mutagenicity and genotoxicity of drinking water in guelma region, algeria. Environmental Monitoring and Assessment, 187(2), 21. http://www.doi.org/10.1007/s10661-014-4223-6

Bain, R., Cronk, R., Wright, J., Yang, H., Slaymaker, T. and Bartram, J., 2014. Fecal contamination of drinking-water in low- and middle-income countries: a systematic review and meta-analysis. PLoS Medicine, 11(5), e1001644. http://www.doi.org/10.1371/journal.pmed.1001644

Bernstein, L., Kaldor, J., Mccann, J. and Pike, M.C., 1982. An empirical approach to the statistical analysis of mutagenesis data from salmonella test. Mutation Research, 97(4), 267281.

http://www.doi.org/10.1016/0165-1161(82)90026-7

Blaise, C., Forghani, R., Legault, R., Guzzo, J. and Dubow, M.S., 1994. A bacterial toxicity assay performed with microplates, microluminometry and microtox ${ }^{\circledR}$ reagent. Biotechniques, 16(5), 932-937. 
Cerna,M., Pastorkovea, A., Smid, J., Dobias, L. and Rossner, P., 1998. The use of YG bacterial tester strains for the monitoring of drinking water mutagenicity. Toxicology Letters (Shannon), 96-97(none), 335-339. http://www.doi.org/10.1016/s0378-4274(98)00090-3

Filipic, M. and Toman, M.J., 1996. Ecotoxicological studies using modified ames bioassay. Water Science and Technology, 34(7-8), 1-7. http://www.doi.org/10.1016/s0273-1223(96)00715-9

Gilbert, S.E. and Rose, L.J., 2012. Survival and persistence of nonspore-forming biothreat agents in water. Letters in Applied Microbiology, 55, 189-194. http://www.doi.org/10.1111/j.1472-765X.2012.03277.x

Hollert, H., Durr, M., Erdinger, L. and Braunbeck, T., 2000. Cytotoxicity of settling particulate matter and sediments of the neckar river (germany) during a winter flood. Environmental Toxicology and Chemistry, 19(3), 528-534. http://www.doi.org/10.1002/etc.5620190302

Hou, Y., Chu, W. and Ma, M., 2012. Carbonaceous and nitrogenous disinfection by-product formation in the surface and ground water treatment plants using yellow river as water source. Journal of Environmental Sciences, 24(7), 12041209. http://www.doi.org/10.1016/s1001-0742(11)61006-1

Karyab, H., Yunesian, M., Nasseri, S., Mahvi, A.H., Ahmadkhaniha, R., Rastkari, N. and Nabizadeh R., 2013. Polycyclic aromatic hydrocarbons in drinking water of tehran, Iran. $\mathbf{J}$ Environ Health Sci Eng, 11(8), 1-7. http://www.doi.org/10.1186/2052-336X-11-25

Kataoka, H., Hayatsu, T., Hietsch, G., Steinkellner, H., Nishioka, S., Narimatsu, S., Knasmüller, S. and Hayatsu, H., 2000. Identification of mutagenic heterocyclic amines (iq, trp-p-1 and $\alpha$ ) in the water of the danube river. Mutation Research/genetic Toxicology \& Environmental Mutagenesis, 466(1), 27-35. http://www.doi.org/10.1016/S1383-5718(99)00235-1

Kusamran, W.R., Tanthasri, N., Meesiripan, N. and Tepsuwan, A., 2003. Mutagenicity of the drinking water supply in bangkok. Asian Pacific Journal of Cancer Prevention Apjcp, 4(1), 31.

Kutlu, M., Aydogan, G., Susuz, F. and Ozata, A., 2004. The salmonella mutagenicity of water and sediments from the porsuk river in turkey. Environmental Toxicology and Pharmacology, 17(2), 111-116. http://www.doi.org/10.1016/j.watres.2012.05.032

Liu, S., Zhu, Z., Fan, C., Qiu, Y. and Zhao, J., 2011. Seasonal variation effects on the formation of trihalomethane during chlorination of water from yangtze river and associated cancer risk assessment. Journal of Environmental Sciences, 23(9), 1503-1511. http://www.doi.org/10.1016/S1001-0742(10)60573-6

Lv, X., Lu, Y., Yang, X., Dong, X., Ma, K., Xiao, S., Xiao, S., Wang, Y. and Tang, F., 2015. Mutagenicity of drinking water sampled from the yangtze river and hanshui river (wuhan section) and correlations with water quality parameters. Scientific Reports, 5, 9572.

http://www.doi.org/10.1038/srep09572

Mamber, S.W., Kolek, B., Brookshire, K.W., Bonner, D.P. and Fungtomc, J., 1993. Activity of quinolones in the ames salmonella TA102 mutagenicity test and other bacterial genotoxicity assays. Antimicrobial Agents \& Chemotherapy, 37(2), 213-217.

http://www.doi.org/10.1128/AAC.37.2.213

Maron, D.M. and Ames, B.N., 1983. Revised methods for the salmonella mutagenicity test. Mutat Res, 113(3), 173-215. http://www.doi.org/10.1016/0165-1161(83)90010-9

Schuetzle, D. and Lewtas, J., 1986. Bioassay-directed chemical analysis in environmental research. Analytical Chemistry, 58(11), 1060A-1075A. http://www.doi.org/10.1016/j.etap.2004.03.005

Vargas, V.M., Motta, V.E. and Henriques, J.A., 1993. Mutagenic activity detected by the ames test in river water under the influence of petrochemical industries. Mutation Research, 319(1), 31. http://www.doi.org/10.1016/0165-1218(93)90028-C

Villanueva, C.M., Kogevinas, M., Cordier, S., Templeton, M.R., Vermeulen, R., Nuckols, J.R., Nieuwenhuijsen, M.J. and Levallois, P., 2014. Assessing exposure and health consequences of chemicals in drinking water: current state of knowledge and research needs. Environmental Health Perspectives, 122(3), 213-221. http://www.doi.org/10.1289/ehp.1206229

Warren, S.H., Claxton, L.D., Diliberto, J., Hughes, T. J., Swank, A., Kusnierz, D.H., Marshall, V. and DeMarini, D.M., 2015. Survey of the mutagenicity of surface water, sediments, and drinking water from the penobscot Indian nation. Chemosphere, 120, 690-696. http://www.doi.org/10.1016/j.chemosphere.2014.10.002

Wu, J.Y., Shen, L., Gao, G., Lin, G.F., Ke, X. and Shen, J.H., 2004. A season-dependent variation of genotoxicity of surface water samples from taihu lake, yangzte delta. Environmental Monitoring and Assessment, 98(1-3), 225-234. http://www.doi.org/10.1023/b:emas.0000038188.16088.f3

Yuan, J., Wu, X. J., Lu, W. Q., Cheng, X. L., Chen, D., Li, X.Y., Liu, A.L., Wu, J.J., Xie, H., Stahl, T. and MerschSundermann, V., 2005. Chlorinated river and lake water extract caused oxidative damage, DNA migration and cytotoxicity in human cells. International Journal of Hygiene \& Environmental Health, 208(6), 481-488. http://www.doi.org/10.1016/j.ijheh.2005.09.002

Zhao, Y., Anichina, J., Lu, X., Bull, R. J., Krasner, S.W. and Hrudey, S.E., 2012. Occurrence and formation of chloro- and bromo-benzoquinones during drinking water disinfection. Water Research (Oxford), 46(14), 4351-4360. http://www.doi.org/10.1016/j.watres.2012.05.032 